ISSN 2078-6441. Вісник Львівського університету. Серія географічна. 2013. Випуск 41. С. 83-90. Visnyk of the Lviv University. Series Geography. 2013. Issue 41. P. 83-90.

$622.83[528.2: 629.78]$

етро олошин

ввівський н ціон льний університет імені в н

вул. рушевського, 4, 79005, м. ввів, кр їн

ведено результ ти моніторингу деформ цій земної поверхні з д ними високоточного нівелюв ння. 'ясов но, що їі осід ння відбув ється під впливом природних і техногенних чинників. еред природних чинників провідну роль відігр $є$ н явність у геологічному розрізі потужної товщі техногенних н копичень, торфів і з торфов них грунтів. ехногенний вплив виявляється через ст тичне н в нт ження від будівель і споруд, вібродин мічний тиск тр нспорту, т кож нтропогенні зміни рівнів підземних вод. йбільші з бсолютним зн ченням деформ ції з фіксов но н вул. овжун .

лючові слов : моніторинг, ендогенні процеси, екзогенні процеси, деформ ція, нівелюв ння, осід ння.

еред $б$ г тьох чинників, що дест білізують екологічну ситу цію н урб нізов них територіях, є деформ ції земної поверхні. они створюють зн чний вплив н середовище життєдіяльності людини, ускл днюють функціонув ння б г тьох типів природнотехнічних геосистем, нерідко призводять до їхнього повного руйнув ння.

еформ ції поверхні є н слідком розвитку у верхніх ш р х літосфери чи н її поверхні процесів різного виду і просторово-ч сового м сшт бу.

они суттєво відрізняються 3 генезою, х р ктером і м сшт 6 ми прояву т небезпекою, яку створюють інженерно-господ рським об'єкт м.

йнебезпечнішими в сейсмічних р йон х ув ж ють деформ ції, зумовлені зсувними т к рстово-суфозійними процес ми. н слідок їхнього розвитку зміщення земної поверхні можуть досяг ти десятків і н віть сотень метрів т спричиняти природнотехногенні в рії й к т строфи. ому вивченню цих процесів приділяють н дзвич йно велику ув гу. хні дослідження, прогнозув ння і вр хув ння у проектув нні, будівництві й експлу т ції споруд є обов'язковими. е регл ментов не низкою держ вних норм тивних документів, що суттєво знижує ризик виникнення н дзвич йних ситу цій. рім того, деформ ції цього типу ост ннім ч сом розгляд ють як в жливий чинник геологічного ризику.

овсім ін кш ситу ція з вивченням і вр хув нням у пр ктичній діяльності повільних, незн чних з бсолютними зн ченнями деформ цій поверхні, зумовлених природними, перш з все ендогенними т природно- нтропогенними процес ми.

видкість розвитку деформ цій цього типу у фізичному ч сі з г лом невелик - від ч сток до 1-2, зрідк 5-10 мм з рік. дн к якщо вони відбув ються протягом трив лого ч су, що особливо в жливо для д вніх міст, то нев жко підр хув ти сум рні зміщення, які можуть зн чно перевищув ти допустимі зн чення. езв ж ючи н очевид-

олошин ., 2013 
ність ск 3 ного, цей тип деформ цій трив лий ч с, поч сти й тепер не вивч ють і не вр ховують у р зі вирішення б г тьох містобудівельних проблем.

ише ост ннім ч сом вони ст ли об'єктом підвищеної ув ги дослідників [2-8]. томість норм тивної б зи, як б регл ментув л необхідність ур хув ння цього типу деформ цій, пр ктично нем . е стримує розробку методологічної, методичної основи т інструмент рію вивчення цих деформ цій, що в кінцевому підсумку підвищує ризик виникнення н дзвич йних ситу цій.

ижче розглянемо результ ти вивчення повільних деформ цій земної поверхні у центр льній ч стині ьвов .

риводом для цього послугув ло м сове ушкодження, в окремих вип дк х і повне руйнув ння великої кількості інженерних об'єктів.

цій ч стині міст, як 1998 р. внесен до списку всесвітньої сп дщини

н лічується близько 200 в рійних будівель, зн чн ч стин яких - цінні п м'ятки рхітектури. водонесучих мереж х щорічно відбув ється сотні в рій.

піт льний ремонт деформов них будинків т ушкоджених комунік цій докорінно ситу ції не змінює. ідремонтов ні споруди т інженерні мережі через певний проміжок ч су продовжують деформув тися.

ентр льн ч стин ьвов розт шов н у меж х ьвівської улоговини, утвореної глибоко вріз ною долиною р. олтви т її приток. но улоговини - це плоск , головно, 3 пл вн тер с р. олтв шириною 500-800 м.

геологічній будові днищ бере уч сть строк тий з літологічним скл дом комплекс люві льно-болотних т люві льних відкл дів, що з ляг ють н розмитій поверхні верхньокрейдових мергелів. розрізі перев ж ють глинисті грунти, ч сто з торфов ні, нерідко $з$ прош рк ми сильно- і середньо розкл деного торфу потужністю до 1,5-2,4 м. ещо менші з площею ділянки скл дені середніми і дрібнозернистими піск ми. поверхні повсюди з ляг є потужн (від 2-3 до 6-9 м) товщ техногенних грунтів.

хили улоговини скл дені верхньокрейдовими мергелями, піск ми нижнього б денію т піщ но-глинистим делювієм, перекритим грунт ми культурного ш ру.

рунтові води поширені головно в днищі улоговини н глибині від 2,0-4,0 до $6,0-10,5 \mathrm{M}$.

ля з'ясув ння причин виникнення кризової ситу ції, що охопил центр міст, у p мк x “ омплексної прогр ми збереження історичної з будови ьвов ”, з твердженої бінетом іністрів кр їни, проведено спеці льні геоекологічні дослідження. і дослідження передб ч ли дет льне (у м сшт бі 1:2 000) інженерно-геологічне, гідрогеологічне, геоморфологічне, історико-геогр фічне вивчення цієї ч стини ьвов . ільне місце було відведено інструмент льним дослідженням деформ цій земної поверхні. ля цього проведено високоточне (другого кл су) нівелюв ння 49 висотних реперів, н ліз і порівняння результ тів н логічних робіт, викон них у 1887, 1914, 1934, 1974 рр. т їхню інтерпрет цію.

підст ві отрим них д них побудов но серію комп'ютерних к ртогр фічних моделей оціночного типу, що х р ктеризують як природну (геологічне середовище), т к і техногенну (будівлі, інженерні мережі тощо) скл дові досліджув них природнотехногенних геосистем. трим ні результ ти свідч ть про досить скл дну, моз їчну к ртину деформ цій земної поверхні, що відбулися з період 31974 по 2001 рік (див. рис. 1). 


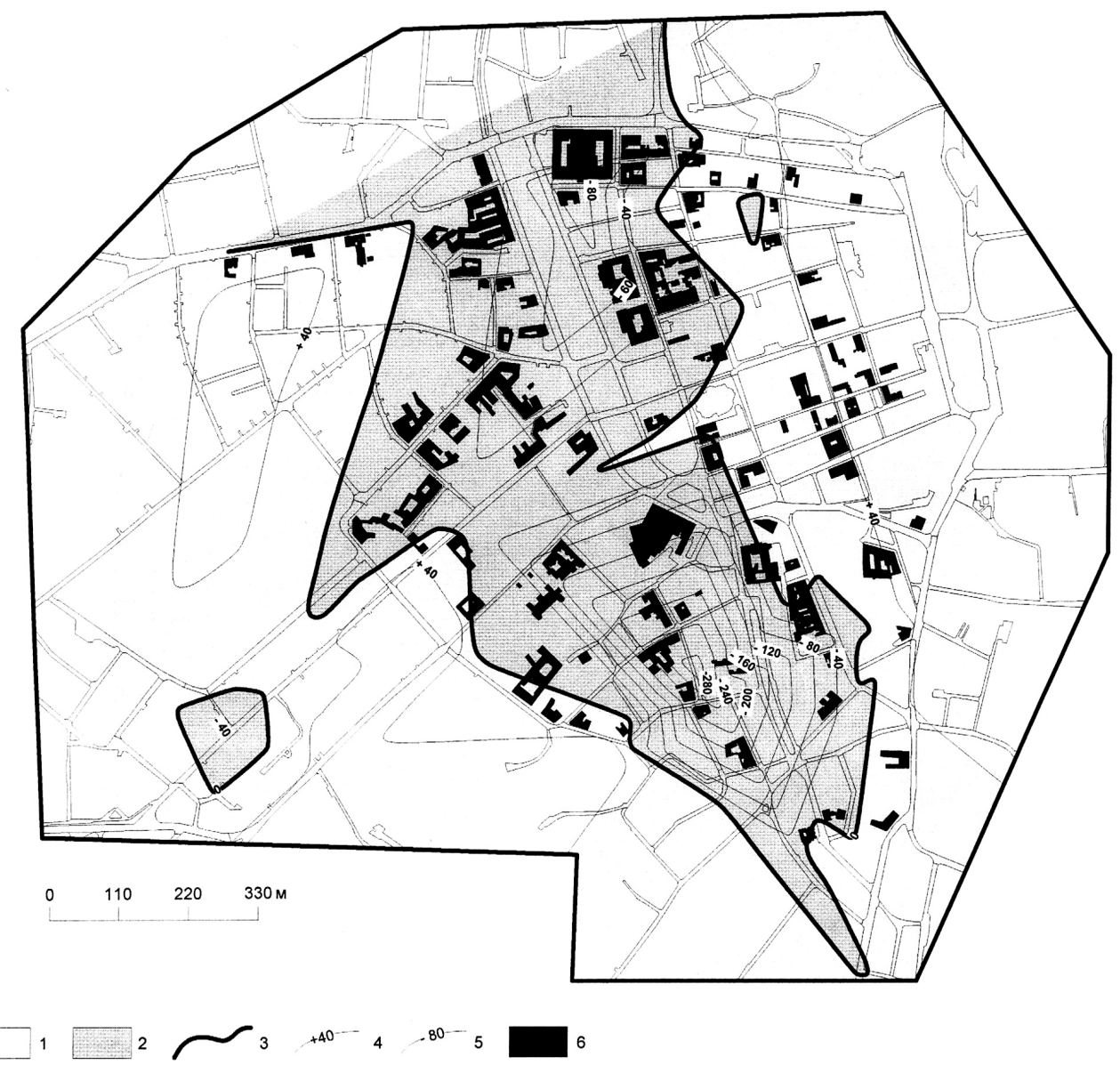

ис. 1. рт деформ цій земної поверхні центр льної ч стини ьвов : 1 - деформ ції земної поверхні з дод тним зн ком; 2 - деформ ції земної поверхні з від'ємним зн ком; 3 - межі ділянок з різним типом деформ цій; 4 - лінії одн кових деформ цій дод тного зн к ; 5 -лінії одн кових деформ цій від'ємного зн к ; 6-будівлі, що з зн ли недопустимих деформ цій.

к 6 чимо з рис. 1, н досліджув ній території є деформ ції дод тного і від’ємного зн ків. ізні з зн ком зміщення поверхні чітко лок лізов ні в просторі. ід’ємні фіксують головно у прирусловій ч стині к н лізов ної олтви, дод тні - н прибортових iї ділянк х т н схил х улоговини.

еформ ції від’ємного зн к 3 бсолютною величиною змінюються від 1,5 до 301,7 мм. од тні колив ються в ді п зоні 0,5-68,3 мм. ум рн мплітуд змін бсолютних позн чок земної поверхні дорівнює 370 мм.

ересічні зн чення від’ємних і дод тних деформ цій ст новлять, відповідно, 64,2 і 32,8 мм. ередня швидкість осід ння поверхні-2,4 мм з рік, піднім ння - 1,2 мм з рік. ро зн чні з інтенсивністю зміщення земної поверхні свідч ть т кож результ ти високоточного нівелюв ння, викон ного у 1887, 1914 і 1934 pp. [11]. 
ксим льні осід ння реперів $з$ 27-річний період ст новили 354 мм, дод тні 3 47 років - 327 мм. ересічні зн чення осід нь з 1887 по 1914 рр. ст новлять 35 мм, з 1914 по 1934 рр. - 29,8 мм.

видкість осід ння поверхні в середньому дорівнює 1,5, піднім ння - 1,3 мм 3 рік. орівняння швидкості перебігу деформ цій у довоєнний ч с і з 1974 по 2001 рр. з свідчило, що осід ння поверхні з ост нні 27 років зросли в 1,6 р 3 . видкість висхідних рухів пр ктично не змінил ся.

фіксов ні в центр льній ч стині ьвов , як охоплює невелику з площею територію (близько $2 \mathrm{kм}^{2}$ ), різнополюсні деформ ції можуть свідчити про їхню полігенетичність. міщення земної поверхні дод тного зн к треб пов'язув ти перш з все з розвитком суч сних тектонічних рухів.

явність висхідних рухів н території ьвов опис н в численних літер турних джерел $\mathrm{x}[1,9,10]$. різними оцінк ми їхня швидкість колив ється в широких меж $\mathrm{x}-$ від 2,9 [10] до 10 мм з рік [1,9]. езв ж ючи н суттєву різницю в бсолютних зн ченнях, з фіксов н чітко вир жен з г льн тенденція. ї існув ння підтверджене і н шими д ними. р вд, виявляються деформ ції цього типу лише н схил х улоговини. дн к пояснити їне походження нетектонічними чинник ми пр ктично неможливо. тосовно суттєвих розбіжностей у швидкості висхідних деформ цій, то вони можуть бути зумовлені нерівномірністю рухів земної кори, недоскон лістю систем вимірюв ння, неодн ковою трив лістю періодів між вимірюв ннями т різними 3 генезою техногенними чинник ми.

росторовий н ліз бсолютних зн чень деформ цій цього типу, н прикл д, з свідчує, що з відд ленням від днищ долини р. олтв вони суттєво зрост ють. цьому ж н прямі зменшується глибин з ляг ння мергелів і потужність пухких відкл дів, що їх перекрив ють. обто пухкі добре стискув ні грунти, з в нт жені зверху інженерними споруд ми, можуть відігр в ти роль своєрідного мортиз тор, що нівелює швидкість суч сних тектонічних рухів.

еформ ції земної поверхні від'ємного зн к м ють, н н ш погляд, іншу природу.

ожливість, інтенсивність т м сшт би їхнього розвитку визн чені як природними, т к і техногенними чинник ми.

еред природних чинників провідну роль відігр є геологічн будов, перш з все літологічний скл д нтропогенових відкл дів т їхня потужність. йконтр стніші осід ння поверхні х р ктерні для ділянок, скл дених сл бкими (сильно стискув ними) пород ми (торфи, з торфов ні, техногенні грунти тощо), зд тними до суттєвого ущільнення під впливом ст тичних і вібродин мічних н в нт жень, зволоження т дегідр т ції. е переконливо доводять д ні, відобр жені н рис. 2.

к 6 чимо з рис. 2, деформ ції від'ємного зн к з'являються н відтинку з великою потужністю техногенних грунтів (пон д 6 м), дещо збільшуються з появою у розрізі 3 торфов них суглинків, досяг ючи н йвищого зн чення н ділянці 3 м ксим льною (до 1,5 м) товщею торфу. дн к с м по собі н явність у розрізі сл бких грунтів, н н ш погляд, не є безпосередньою причиною зн чного 3 інтенсивністю т м сшт 6 ми осід ння земної поверхні. хня н явність, фізико-мех нічні вл стивості т потужність $€$ провідною природною передумовою для розвитку деформ цій. оловною ж рушійною силою в т ких умов х є різний з х р ктером т інтенсивністю техногенний вплив.

еформув ння земної поверхні відбув ється головно вн слідок ущільнення сл бких грунтів під впливом ст тичного н в нт ження, створеного потужною (від 3-6 до 9 м) товщею грунтів культурного ш ру т щільною периметр льною з будовою території. 
ехногенні грунти з огляду н н явність зн чної кількості орг ніки т її окиснення зд тні, крім того, до с моущільнення. ум рний нтропогенний тиск н б г тьох ділянк х перевищує 0,2-0,3 , зумовлюючи розвиток у глинистій товщі процесів консолід ції т об’ємної повзучості.
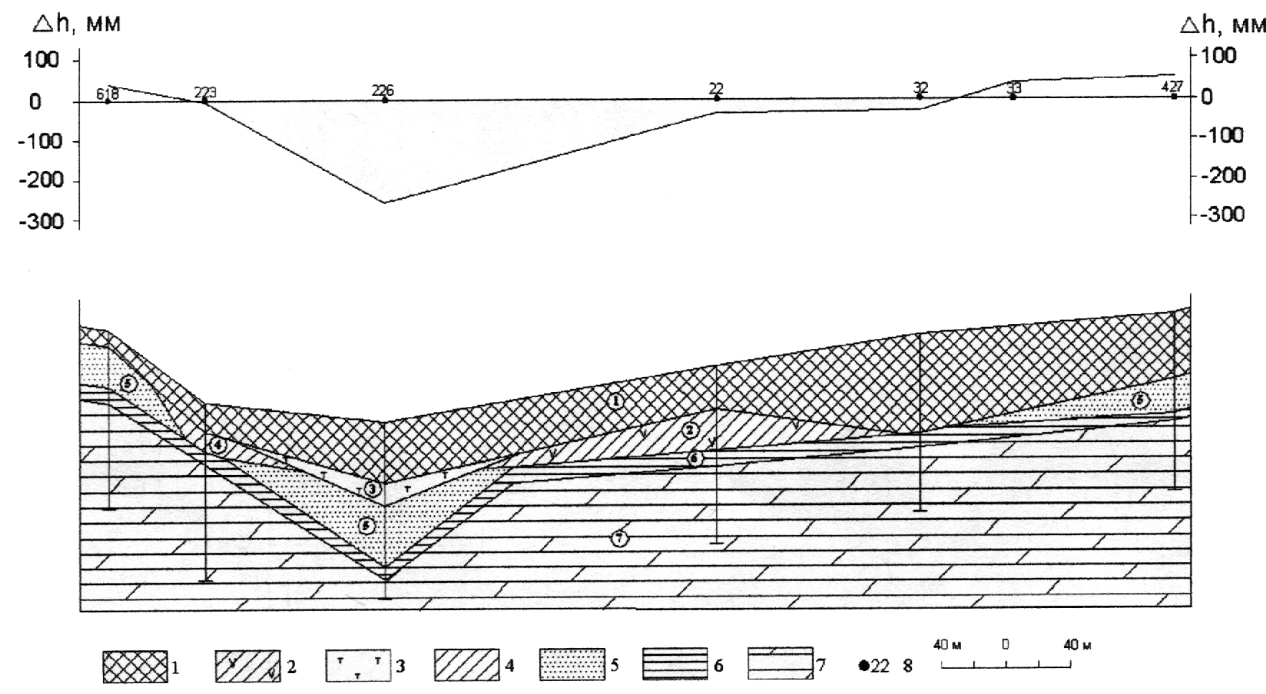

ис. 2. ертик льні рухи висотних реперів (1974?2001) т їхній зв'язок з геологічною будовою: 1 - техногенні грунти; 2 - 3 торфов ні суглинки; 3 - торфи; 4 - суглинки; 5 - піски; 6 - глини; 7 - мергелі; 8 - номер висотного репер .

кож дод ткове осід ння поверхні стимульов не вібр ційним н в нт женням від тр нспорту. плив цього чинник дет льно вивчено в ході спеці льних геотехнічних досліджень для к піт льного ремонту те тру опери й б лету. овготрив лими компресійними дослід ми з'ясов но, що генеров не різними вид ми тр нспорту (передусім рейкового) вібр ційне поле прискорює розвиток деформ цій об'ємної повзучості сл бких грунтів н $15-30 \%$.

отужним чинником, що прискорює процеси осід ння поверхні, є дегідр т ційне ущільнення н сичених водою сл бких грунтів у місцях дрен жу грунтових вод пошкодженими підземними інженерними мереж ми т зміни вл стивостей порід н ділянк $\mathrm{x}$ нтропогенного підтоплення.

ведені д ні з свідчують, що бсолютні зн чення осід ння земної поверхні визн чені головно будовою і вл стивостями геологічного середовищ, x p ктером, інтенсивністю і трив лістю нтропогенного впливу н нього.

ході розгляду причин і з кономірностей розвитку осід нь земної поверхні з кономірно пост є пит ння про роль у цьому процесі техногенного чинник . зн чні з швидкістю зміщення природно- нтропогенної генези не лише компенсують незн чні з розміром висхідні суч сні тектонічні рухи, й зн чно перевищують їх.

езв ж ючи н ур хув ння результ тів новітніх досліджень суч сних тектонічних рухів $[2,3]$ не треб повністю відкид ти й дещо іншого сцен рію розвитку деформ тивних процесів н досліджув ній ділянці. уть його поляг $є$ в тому, що у сфері дин міч- 
ного впливу пл тформних сейсмічних розломів різного типу і порядку можуть виник ти зони геодин мічних ном лій. і ном лії м ють високу мплітуду вертик льних i горизонт льних рухів (до 50-70 мм з рік), коротку періодичність (0,1-1,0 рік), просторову лок ліз цію $(0,1-1,0$ км), пульс ційну і зн козмінну спрямов ність [3]. ожливість розвитку деформ цій т кої генези зумовлен тим, що долин олтви з кл ден вздовж тектонічного порушення, що простяг ється у н прямі сіки- нопків- олоско. ро зн чні тектонічні рухи від'ємного зн к в нед лекому минулому свідчить т кож зн чн $з$ потужністю товщ відкл дів голоцену. ст точну відповідь н пит ння про роль тектонічного чинник у розвитку процесів осід ння центр льної ч стини ьвов можуть д ти лише спеці льно орг нізов ні спостереження з зміщенням поверхневих і глибинних (з кл дених у мергелі) реперів.

н ліз к рт, які відобр ж ють деформ ції земної поверхні й в рійність будівель (див. рис. 1) з свідчив, що перев жн більшість в рійних споруд розт шов н н території, як 3 зн є різних з м сшт бом осід нь. стин із них розміщен у межовій зоні, де зн к деформ цій змінюється н протилежний. ещо менш , одн к т кож досить велик кількість ушкоджених об'єктів є в р йоні, для якого х р ктерні висхідні тектонічні рухи. н логічних умов х розт шов ні й ділянки, де з фіксов но 6 г тор зові (в одному й тому ж місці) повторення в рійних ситу цій н водоносних мереж х. иведення їх з л ду призводить до зн чних економічних т екологічних збитків. озгерметиз ція к н ліз ційних колекторів, н прикл д, супроводжується низкою супутніх процесів, т ких як нтропогенн суфозія, підтоплення, з бруднення грунтових і підземних вод тощо.

езумовно, повільні деформ ції земної поверхні не $є$ універс льною причиною ушкодження і руйнув ння різних типів інженерно-господ рських об'єктів, одн к небезпек , яку породжують ці процеси, д є підст ви розгляд ти їх як в жливий чинник геодин мічного ризику урбосистем. вип дку виникнення землетрусів швидкість розвитку цих деформ цій може суттєво збільшув тись.

огляду н це вони потребують дет льного комплексного вивчення. птим льним способом ре ліз ції цього вкр й в жливого й кту льного 3 вд ння $є$ створення в центр льній ч стині ьвов , згодом і н всій його території спеці льного геодин мічного полігон , у його меж х доцільно з кл сти 6 зову мережу глибинних (вст новлених у мергелі) і поверхневих реперів. і репери треб розт шув ти у місцях лок ліз ції мережі точок комплексного геоекологічного моніторингу.

цих точк х ведуть спостереження з гідродин мічним і гідрохімічним режимом грунтових і ртезі нських вод, змін ми ст ну і фізичних вл стивостей гірських порід.

діоізотопні вимірюв ння коефіцієнт пористості грунтів культурного ш ру, які проводять у цьому р йоні міст свідч ть про поступове ущільнення породного м сиву.

инхронні спостереження з зміщенням поверхневих і глибинних реперів д дуть змогу оцінити роль тектонічного і техногенного чинник у їхньому розвитку, т кож виявити особливості впливу нтропогенних змін окремих скл дових геологічного середовищ н дин міку деформ ційних процесів.

езульт ти т ких комплексних спостережень слугув тимуть н дійною інформ ційною основою для прогнозу деформ цій і розробки н уково-обгрунтов них з ходів із з безпечення стійкості природно-технічних геосистем, підвищення рівня екологічної комфортності прожив ння у центр льній ч стині ьвов . 


\section{СПИСОК ВИКОРИСТАНОЇ ЛІТЕРАТУРИ}

1. офштейн . . рт современных вертик льных движений земной коры 3 п дной ч сти кр ины / . . офштейн, . . омов // овременные движения земной коры. - 1973. - № 5. - . 89-93.

2. узьмин . . ценк геодин мического риск объектов нефтег зового комплекс / . . узьмин // унд мент льный б зис новых технологий нефтяной и г зовой промышленности. - . . : ук , 2000. - . 334-344.

3. узьмин . . овременные суперинтенсивные деформ ции земной поверхности в зон х пл тформенных р зломов / . . узьмин // еологическое изучение и использов ние недр : н учно-технический сборник. - . : еоинформм рк, 1996. ып. 4. - . 43-53.

4. есмеянов . . ыявление и прогноз оп сных р зрывных тектонических смещений при инженерных изыск ниях для строительств / . . есмеянов, . . рин , . . тынин [и др.] // нж. геология. - 1992. - № 2. - . 17-31.

5. лиенко . . проблеме оценки эколого-неогеодин мического риск в кр ине / . . лиенко // тері ли н ук.-пр кт. конф. - ., 1997. - .93-97.

6. лієнко . . онцепту льні з с ди оцінки еколого-неогеодин мічного ризику / . . лієнко // ук.-техн. симпозіум. еомоніторинг-99 (13-16 листоп д 1999 р. - оршин; ьвів, 1999. - . 70-73.

7. лієнко . о проблеми суч сного геоморфогенезу т оцінки геодин мічного ризику / . лієнко // кр їн т глоб льні процеси: геогр фічний вимір. - .; уцьк, 2000. - .2. - .70-74.

8. кобков . . оль природных и нтропогенных геологических процессов в р звитии вертик льных смещений земной поверхности г. осквы / . . кобков // руды . . ., 1972. - .16. - .13-17.

9. околовский . . етодик поэт пного изучения неотектоники / . . околовский, . . олков. - иев : ук. думк , 1965. - 135 с.

10. омов . . овременные вертик льные движения земной коры 3 п дных р йонов кр ины / . . омов. - иев : ук. думк , 1977. - .3-9.

11. Wilczkiewicz E. Niwelacja precyzyjna na obszarze Wielkego Lwowa wykonana w roku 1934 / . Wilczkiewicz // Czasopismo Techniczne. - Lwow, 1936. - N 5. - . 54. S. 97-104. 


\title{
MONITORING OF GEODYNAMIC PROCESSES IN CENTRAL PART OF LVIV
}

\section{Petro Voloshyn}

Ivan Franko National University of Lviv,

\author{
M. Hrushevskyi St., 4, UA - 79005 Lviv, Ukraine
}

The results of earth surface deformations monitoring are brought from data of the high-fidelity leveling. Her settling takes place under influence of natural and technogenic factors. Among natural factors a leading role playing presence in the geological cut a powerful layer of technogenic accumulations, turfs and at turf soils. Technogenic influence appears through the static pressure from building and facilities, vibration-dynamic pressure of transport, and anthropogenic changes of underwaters levels.

Maximum of deformations absolute value are fixed on the Kovzhun Street.

Key words: monitoring, endogenous processes, exogenous processes, deformation, leveling, settling.

етр олошин

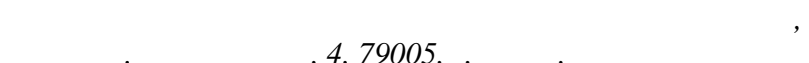

риведено результ ты мониторинг деформ ций земной поверхности по д нным высокоточного нивелиров ния. ст новлено, что ее осед ния происходят под влиянием природных и техногенных ф кторов. реди природных ф кторов ведущую роль игр ют н личие в геологическом p зрезе мощной толщи техногенных н коплений, торфов и 3 торфов нных грунтов. ехногенное влияние проявляется з счет ст тической з грузки от зд ний и сооружений, вибродин мического д вления тр нспорт , т кже нтропогенных изменений уровней подземных вод.

ибольшие 3 бсолютной величиной деформ ции з фиксиров нын ул. овжун .

лючевые слов : мониторинг, эндогенные процессы, экзогенные процессы, деформ ция, нивелиров ние, осед ние. 